\title{
Cenomanian-Turonian Foraminiferal Zones of West Siberian Province and Their Correlation with Canadian Province
}

\author{
V. M. Podobina \\ Tomsk State University, Tomsk, Russia \\ Email: podobina@ggf.tsu.ru
}

How to cite this paper: Podobina, V.M. (2017) Cenomanian-Turonian Foraminiferal Zones of West Siberian Province and Their Correlation with Canadian Province. Open Journal of Geology, 7, 1176-1187. https://doi.org/10.4236/ojg.2017.78078

Received: May 12, 2017

Accepted: August 18, 2017

Published: August 21, 2017

Copyright $\odot 2017$ by author and Scientific Research Publishing Inc. This work is licensed under the Creative Commons Attribution International License (CC BY 4.0).

http://creativecommons.org/licenses/by/4.0/

\section{(c) (i) Open Access}

\begin{abstract}
Data on Late Cenomanian and Early Turonian foraminiferal assemblages in the northern palaeo biogeographical district of the West Siberian province are summarized in the paper. In addition, the section of borehole 1016 of the Parusovaya area located in the far north of the province is considered. New information on the foraminiferal zones of this stratigraphic level along with the previously known sections of the Tazovskaya, Purpeiskaya, Van-Eganskaya areas provided an opportunity to carry out a correlation of these zones between the West Siberian and the Canadian provinces (Western Canada, Northern Alaska). The West Siberian Late Cenomanian Trochammina wetteri tumida, Verneuilinoides kansasensis and the Early Turonian Gaudryinopsis angustus foraminiferal zones have their analogues as similar zones in the $\mathrm{Ca}$ nadian province. Due to the provided correlation of the micropalaeontological (foraminiferal) zones, their age in the West Siberian province has been clarified. Besides, similarity of the conditions of dwelling within the boundaries of the entire Arctic palaeobiogeographical realm has been observed.
\end{abstract}

\section{Keywords}

Foraminifera, Upper Cenomanian, Lower Turonian Zones, Correlation, West Siberian, Canadian Provinces

\section{Introduction}

A comparative characteristic of Late Cretaceous West Siberian foraminiferal assemblages and other provinces of the Northern hemisphere has shown that the Cenomanian-Turonian assemblages are significantly distinctive in their systematic composition but correspond to those of the Canadian province (Western 
Canada, Northern Alaska) within the boundaries of the Arctic palaeobiogeographical realm [1] [2] [3] [4].

The layers of Cenomanian-Turonian assemblages of Western Siberia had been earlier attributed to the microfaunistic zones (upper Uvatskian, Kuznetsovskian Horizons) by the author of the paper. The assemblages of interest are similar in their systematic composition with time-equivalent assemblages of the analogous zones of Western Canada and Northern Alaska formations attributed to the Canadian province. One should observe a similarity not only at the generic but at specific levels in the Cenomanian and Turonian assemblages. Apparently, it is due to the existence of unimpeded associations between the basins of Western Siberia and Northern America and a similarity of the conditions of existence. In the compared assemblages one can observe almost a general generic composition and a high percent (up to 60\%) of similar species, vicariants (geographical substitutes of a related taxon) and geographical subspecies. In all the compared assemblages with the exception of those from the far away areas, agglutinated quartz-siliceous shells are predominant. A similar, specific composition of plankton (pelagic) forms assigned to the lower Turonian stratigraphic level is of great interest. However, a comparison of the Cenomanian-Turonian assemblages of Western Siberia with those of Arctic Canada and the Canadian Arctic Archipelago [5] [6] revealed a considerable impoverishment of the latter, and among the assemblages of Arctic Canada there are no even general generic taxa except primitive forms. It is probably accounted for by a considerable shallowing of the area concerned which brought about unfavourable conditions for the existence of more highly organized foraminifera [1] [2] [3] [4].

The paper concerned presents results of researching Late Cenomanian and Early Turonian foraminifera from this stratigraphical level of northern palaeobiogeographical district of West Siberian province. This is one of the five districts named according to the cardinal points [1] [7] [8]. Late Cenomanian assemblages had been previously studied in the upper parts of the Uvatskian Horizon from the sections of a number of boreholes of the Tazovskaya, Purpeiskaya, Van-Eganskaya areas located southwards just in the same palaeobiogeographical district (Figure 1). Continuation of the research of Late Cenomanian and Early Turonian foraminifera in the basin of the northern district is due to the identification of this biota (the Parusovaya area located eastwards Yamal). The present paper describes results of the section studies of this area providing new data on the Cenomanian-Turonian. The correlation of the CenomanianTuronian foraminiferal zones of West Siberian and the Canadian provinces within the boundaries of the Arctic realm is provided (see Table 1).

\section{Previous Research}

Research of Cenomanian foraminifera from the Uvatskian Horizon in Western Siberia has been carried out since the 50-s of the last century. Only a fragmentary amount of information on isolated foraminifera in this part of the section has 


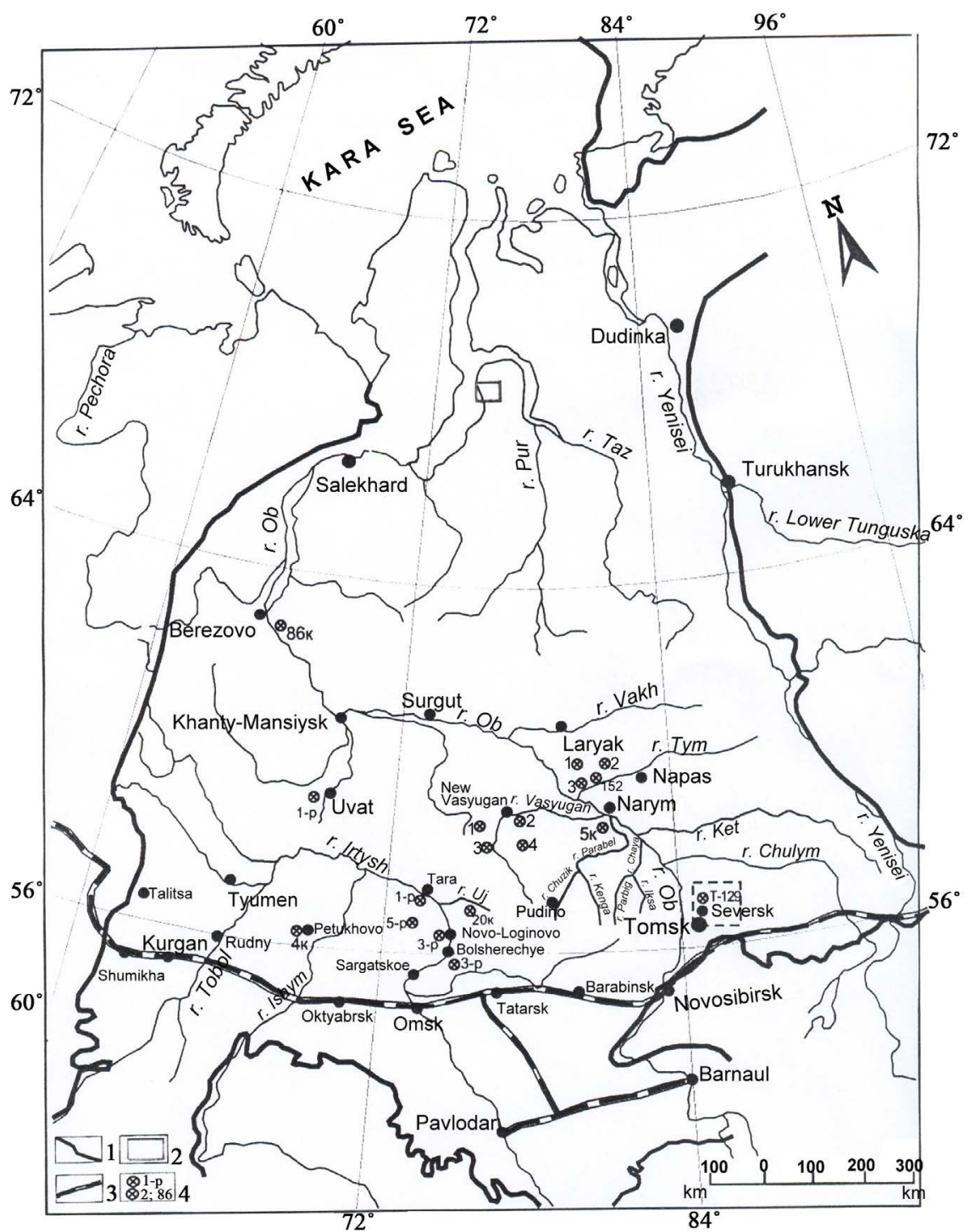

Figure 1. Research district (Parusovaya area). 1: boundary of West-Siberian plain; 2: Parusovaya area; 3 : railways; 4 : boreholes of various depths.

been provided in the works published by [9] [10] [11] [12]. Findings of Cenomanian foraminifera from the Uvatskian Horizon of Transuralia are mainly well-known. In the northern district they were first discovered by V. M. Podobina in marine deposits of the Uvatskian Horizon [13].

The Uvatskian Horizon in the northern district consists of grey aleurolites and light-grey millstone grit of the marine genesis. The rocks comprise coarse-grained agglutinated quartz-siliceous foraminifera which are practically the only basis for establishing the Cenomanian age of this Horizon.

The foraminifera of Early Cenomanian of seven sections of Van-Egansky area's boreholes have been studied in detail, so in the shallow water fascies of the Uvatskian Horizon two foraminiferal zones: Saccammina micra, Ammomarginulina sibirica (lower zone), Trochammina wetteri tumida, Verneuilinoides kansasensis (upper zone) with the layers of Gaudryinopsis nanushukensis at the 
Table 1. Scheme of Cenomanian-Turonian foraminiferal zone correlation of West Siberian and Canadian provinces in Arctic realm.

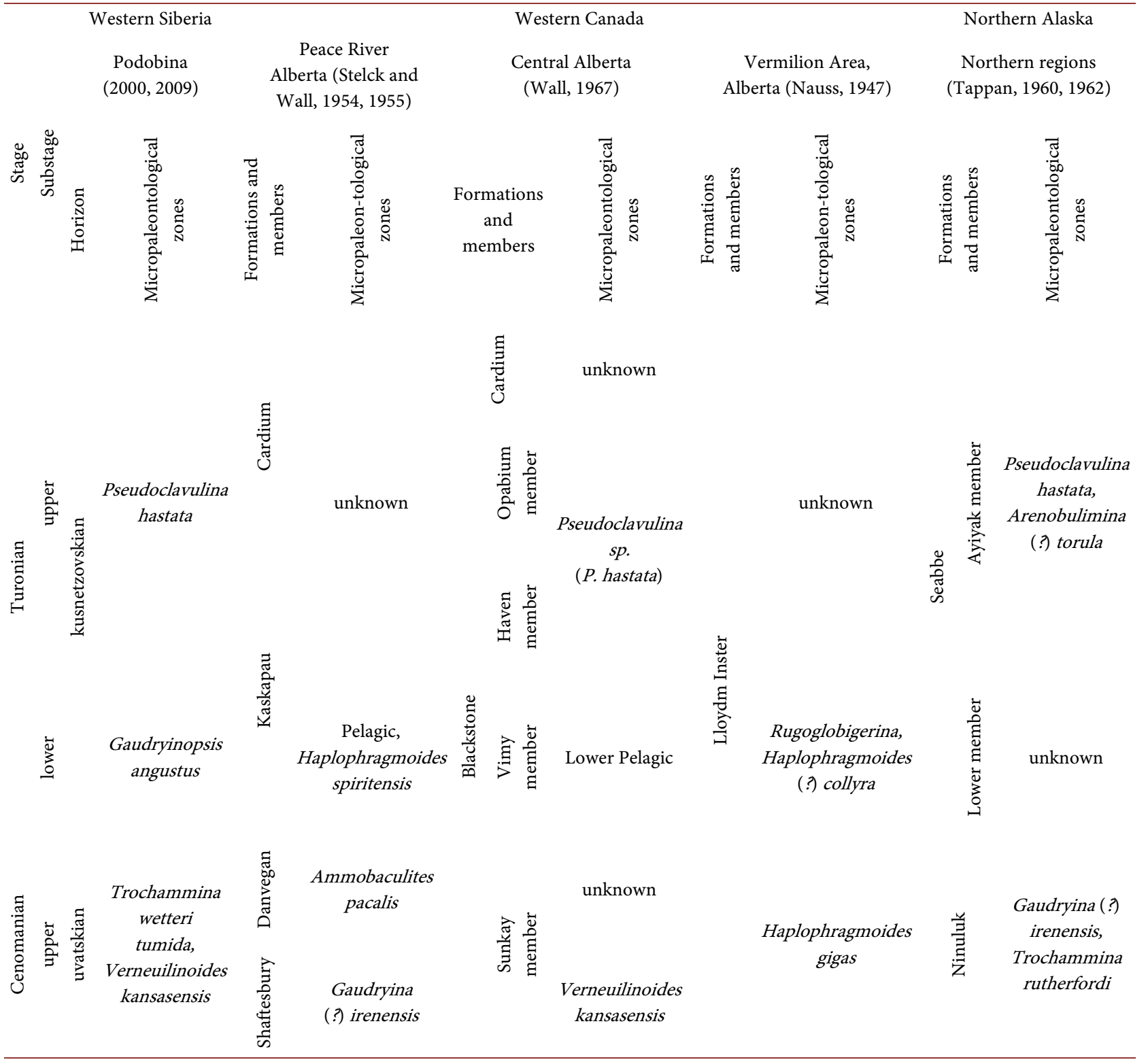

base of the upper zone [7] [8] [14] had been established earlier by the author. In all other areas except the northern area and Transuralia Uvatskian Horizon is represented by continental fascies containing plant remains and spore and pollen complexes.

Data on two Turonian foraminifera zones are known in many works of V.M. Podobina [2] [3] [4]. These foraminifera are abundant in the Kuznetsovskian Horizon of a marine genesis throughout the area of Western Siberia.

The determination of the age of the Uvatskian and Kuznetsovskian Horizons is of great practical value because industrial hydrocarbon reserves are assigned to the Uvatskian Horizon and the Kuznetsovskian Horizon is a cap rock which has kept these hydrocarbons from destruction. 


\section{Material and Methods}

Biostratigraphy of upper Cenomanian - lower Turonian deposits of the northern district of Western Siberia has been the object of much experimentation. Twenty core samples selected in the section of borehole 1016 of the Parusovaya area located eastwards of Yamal (Figure 1) served as the additional material to study. Foraminifera of various systematic composition represented by agglutinated quartz-siliceous shells were discovered as a result of the microfaunistic analysis.

Systematic composition of Late Cenomanian and Early Turonian foraminifera assemblages in the section of borehole 1016 was distinguished and their stratigraphic significance was established, too. The micrograps (Figures 2-4) illustrate several species including index-species of late Cenomanian and two Early Turonian foraminifera assemblages. In Figure 5 one can see the intervals of depths of core selection in the section of borehole 1016 from the samples of which foraminifera have been extracted.

The boundary between the Uvatskian and Kuznetsovskian Horizons is drawn arbitrarily mainly according to the geological data. The lithological and microfaunistic characteristic of the section being studied is made coincident with the biostratigraphic data of both Horizons as well as the identification of index species of the determined assemblages and the corresponding foraminifera zones (Figure 5).

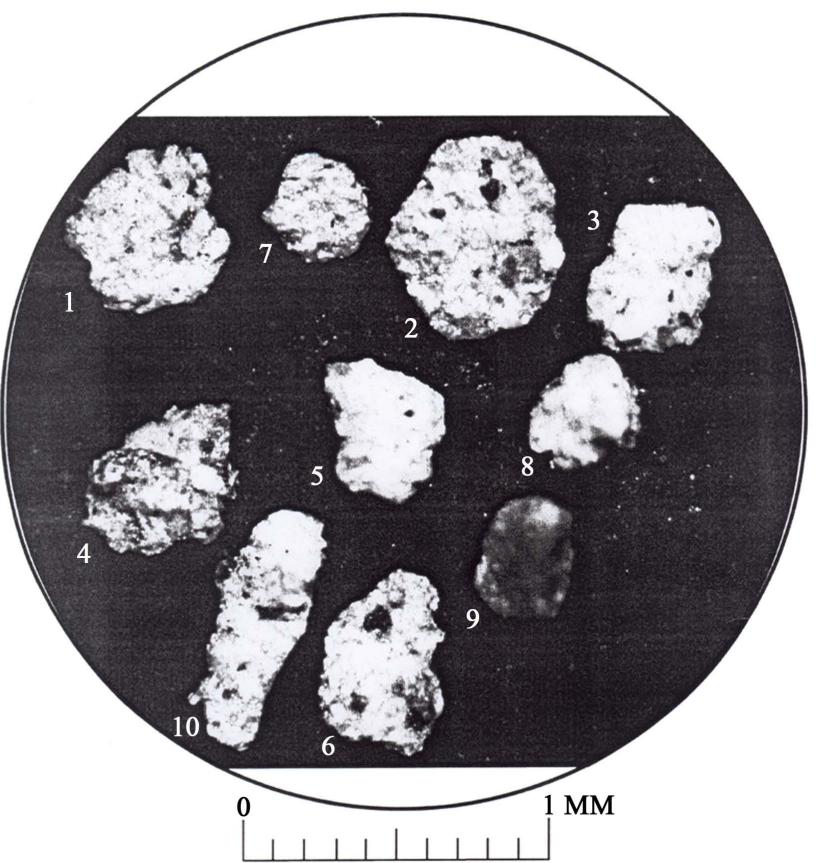

Figure 2. Foraminifera assemblage with Gaudryinopsis nanushukensis elongatus. Western Siberia, Parusovaya borehole 1016, interval 1040.5 - $1048.8 \mathrm{~m}, 1.45 \mathrm{~m}$ beginning of core, depth $1041.95 \mathrm{~m}$; Cretaceous system $(\mathrm{K})$, upper part $\left(\mathrm{K}_{2}\right)$, Cenomanian stage $\left(\mathrm{K}_{2} \mathrm{~cm}\right)$, upper substage $\left(\mathrm{K}_{2} \mathrm{~cm}_{2}\right)$, Uvatskian Horizon. 1 - 2: Haplophragmoides $\mathrm{cf}$. variabilis Podobina; 3 - 6: Ammomarginulina cf. sibirica Podobina; 7 - 9: Trochammina aff. wetteri Stelck et Wall tumida Podobina; 10: Gaudryinopsis aff. nanushukensis (Tappan) elongatus Podobina. 


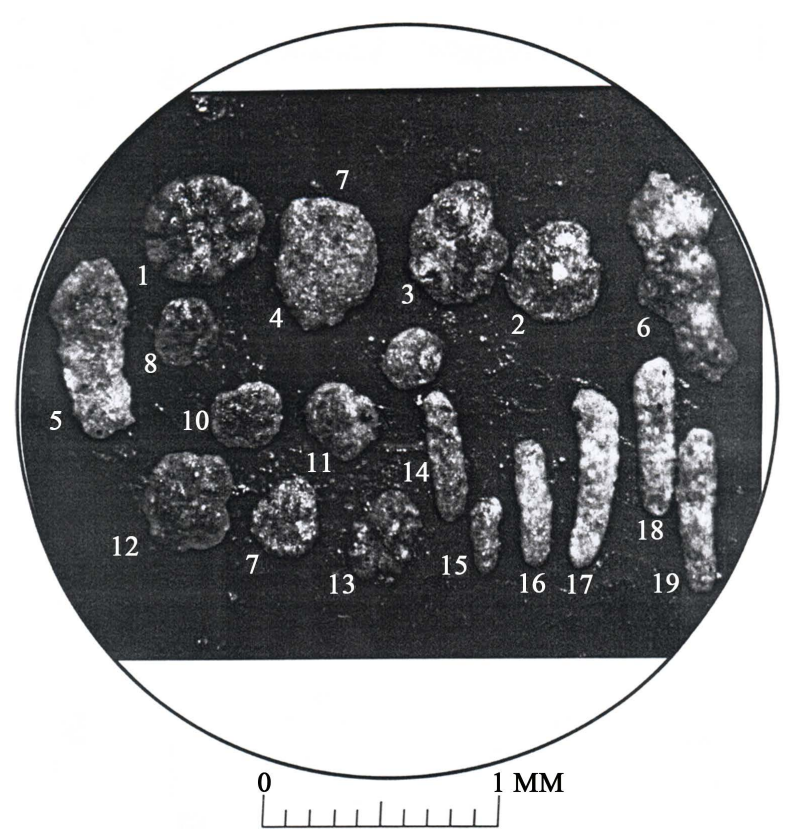

Figure 3. Foraminifera assemblage with Gaudryinopsis angustus. Western Siberia, Parusovaya borehole 1016, interval 1012.0 - $1019.9 \mathrm{~m}, 4.65 \mathrm{~m}$ beginning of core, depth 1016.65 $\mathrm{m}$; Cretaceous system $(\mathrm{K})$, upper part $\left(\mathrm{K}_{2}\right)$, Turonian stage $\left(\mathrm{K}_{2} \mathrm{t}\right)$, lower substage $\left(\mathrm{K}_{2} \mathrm{t}_{1}\right)$, Kuznetsovskian Horizon. 1: Labrospira stata Podobina; 2: Labrospira collyra (Nauss); 3: Haplophragmoides rota Nauss sibiricus Zaspelova; 4: Asarotammina antisa Podobina; 5 6: Haplophragmium incomprehensis (Ehremeeva); 7 - 12: Trochammina wetteri Stelck et Wall; 13: Trochammina subbotinae Zaspelova; 14 - 19: Gaudryinopsis angustus Podobina.

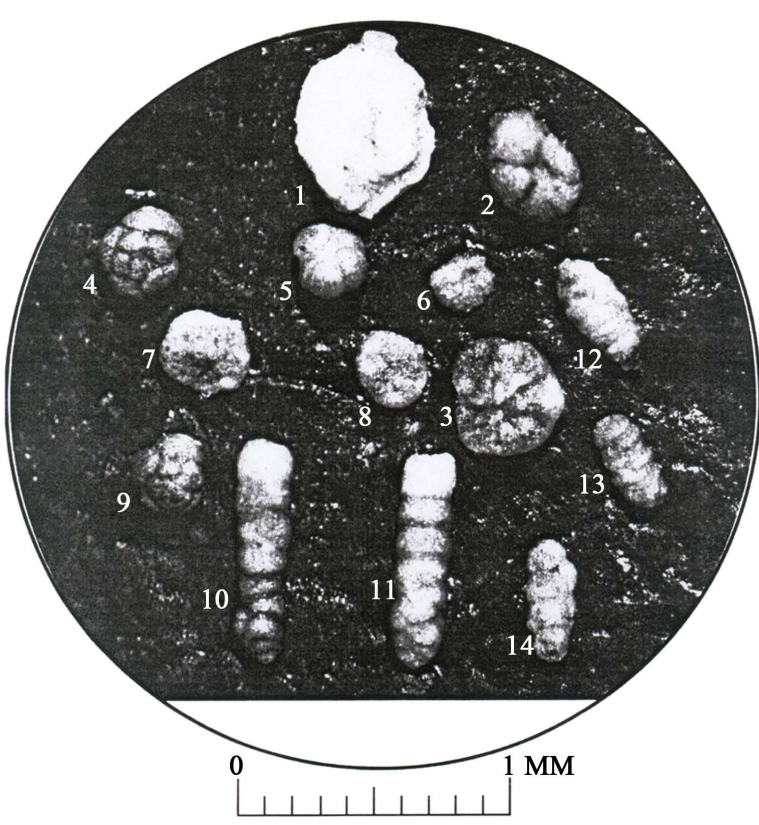

Figure 4. Foraminifera assemblage with Guadryinopsis angustus. Western Siberia, Parusovaya borehole 1016, interval 1012.0 - $1019.0 \mathrm{~m}, 5.4 \mathrm{~m}$ beginning of core, depth 1017.4 $\mathrm{m}$; Turonian stage $\left(\mathrm{K}_{2} \mathrm{t}\right)$, lower substage, Kusnetsovskian Horizon. 1: Lituotuba cf. confusa (Zaspelova); 2: Haplophragmoides crickmayi Stelck et Wall; 3: Haplophragmoides rota Nauss sibiricus Zaspelova; 4 - 9: Trochammina wetteri Stelck et Wall; 10 - 11: Pseudoclavulina hastata (Cushman); 12 - 14: Gaudryinopsis angustus Podobina. 


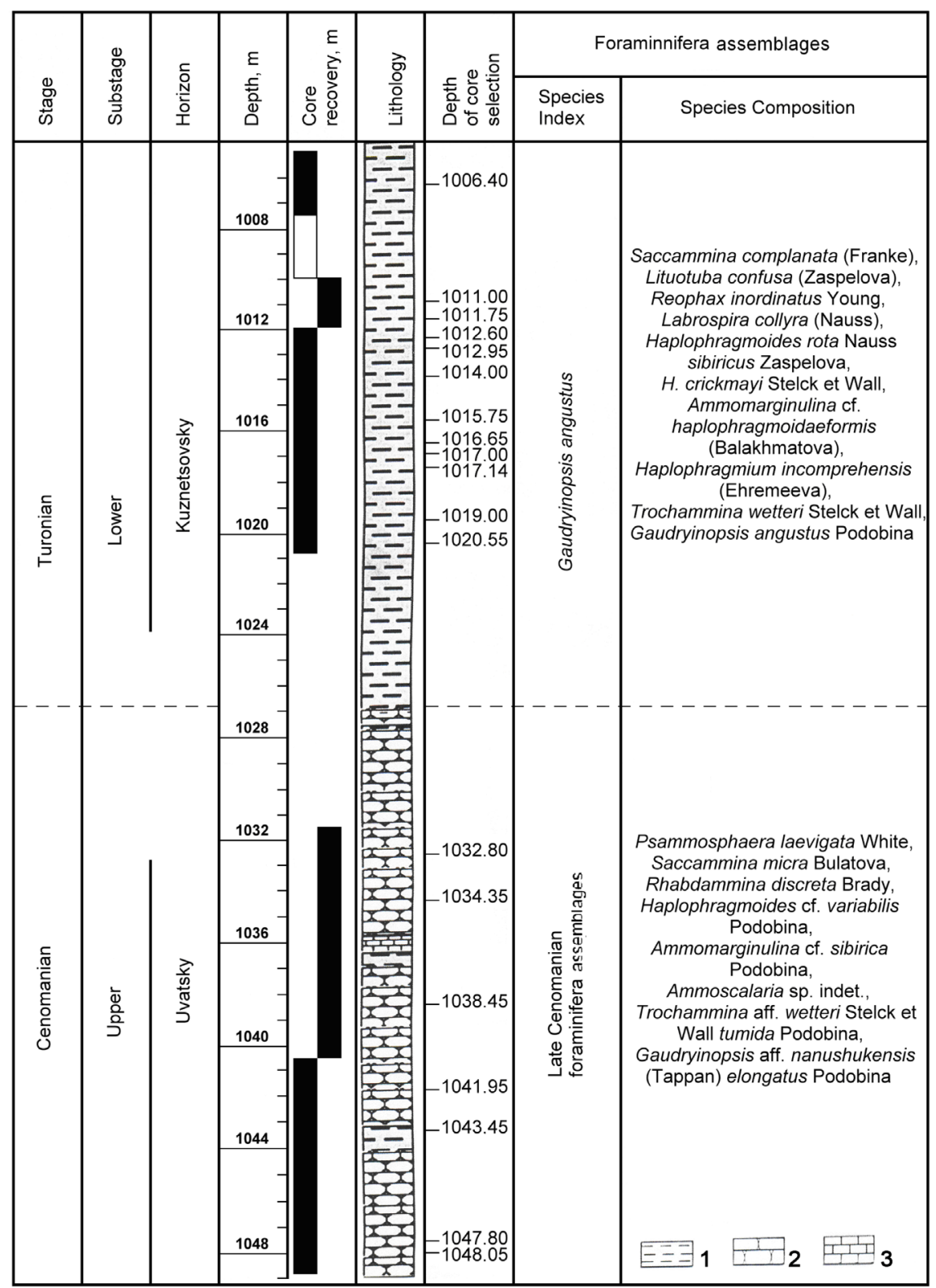

Figure 5. Lithology and microfaunistic Cenomanian-Turonian characteristic of the section of the Parusovaya borehole 1016 (interval $1006.40 \mathrm{~m}-1048.05 \mathrm{~m}$ ). 1: argillite; 2: millstone grit; 3: carbonized millstone grit.

The Asarotammina genus previously established by P. Bronniman in the Holocene of the Brazilian shelf was first discovered for Western Siberia in the lower Turonian stage of the Parusovaya area.

A new Early Turonian species of the genus concerned-A. antisa Podobina is different from the standard Holocenian one and is found in the lower Turonian stage in the north [7].

Assemblage with Gaudryinopsis nanushukensis elongatus of Late Cenoman discovered in the section of borehole 1016 of the Parusovaya area differs from that of Van-Eganskaya and other areas [14]. It is significantly impoverished in 
its systematic composition, agglutinated quartz-siliceous shells of separate species are poorly preserved, and it is not easy at all to establish index-species and characteristic accompanying species.

Early Turonian assemblage with Gaudryinopsis angustus established almost in all the selected samples of the section of borehole 1016 from the bottom of the Kuznetsovskian Horizon is diverse, and index-species is predominant. This assemblage is identical with the complexes studied by V. M. Podobina in many sections of Western Siberia [2] [3] [7]. Background information of the foraminiferal assemblages and Cenomanian-Turonian biostratigraphy of the section, borehole 1016 of Parusovaya area in the far North of West-Siberian province (northern district) which comes close to the micropalaeontological zones of the Canadian province was added for comparison.

\section{Results of Investigation}

\subsection{Cenomanian and Turonian Biostratigraphy}

\subsubsection{Cenomanian Stage}

Cenomanian stage and its deposits of marine genesis in the northern district were first distinguished by V.M. Podobina [13] on the basis of the finds of distinctive Inoceramus pictus Sowerby and foraminifera. Later on, Cenomanian foraminifera assemblages were discovered in the sections of the Uvatskian Horizon in other areas of the northern district. They suggest marine conditions of deposits' formation due to the emergence of Late Cenomanian boreal transgression [8]. Late Cenomanian foraminifera of seven sections of boreholes of the Van-Eganskaya area [14] had been previously studied in detail. In the section of borehole 1016 of the Parusovaya area being studied only the layers with Gaudryinopsis nanushukensis elongatus of the bottom of the upper zone-Trochammina wetteri tumida, Ammobaculites kansasensis earlier established for the part of the section concerned have been traced.

\section{Upper Substage Uvatskian Horizon}

From the rocks with the interval 1031.5 - $1048.8 \mathrm{~m}$ (borehole 1016) eight samples from noncalcareous grey aleurolites with sublayers of light-grey millstone grit traced have been selected. Grains of quartz, mica plates, separate agglutinated big-grained foraminiferal shells, black chitinous shell linings in the form of imprints of their former chambers are predominant in the washed-out big-grained fractions. Most of foraminifera shells from the Uvatskian Horizon of the area concerned are poorly preserved so that species character is difficult to distinguish. Along with the indicated remains of organisms, yellowish fragments of diatomaceous flora in the form of small rounded disks are encountered.

In all 8 samples selected from the Uvatskian Horizon hardly distinguishable remains of foraminiferal shells are predominant. Along with them, however, the species of Late Cenomanian mainly without species determinations-Haplophragmoides, Ammomarginulina, Trochammina, Verneuilinoides, Gaudryinopsis were established among well preserved forms. Along with them, index-species of 
one of the assemblages-Gaudryinopsis nanushukensis elongatus-was distinguished (Figure 2).

In some samples studied the following species-Psammosphaera laevigata White, Saccammina micra Bulatova, Rhabdammina discreta Brady, Haplophragmoides cf. variabilis Podobina, Ammomarginulina cf. sibirica Podobina, Ammoscalaria sp. indet, Trochammina aff. wetteri Stelck et Wall tumida Podobina, Gaudryinopsis aff. nanushukensis (Tappan) elongatus Podobina are determined. Flattened remains of the shells of Ammomarginulina and Trochammina genera are the most numerous ones.

Separate pseudomorphoses of calcareous shells of foraminifera Rotaliida order and ostracoda are established. It is necessary to update data on foraminifera and stratigraphy of Cenomanian-Turonian northern district of Western Siberia because industrial and renewable hydrocarbon reserves are assigned to this part of the section.

\subsubsection{Turonian Stage}

\section{Lower Substage Kuznetsovskian Horizon}

Well-preserved agglutinated quartz-siliceous foraminifera were discovered in 12 samples from the interval 1005.0 - $1019.9 \mathrm{~m}$ of the section (borehole 1016). Lithologically, the samples are represented by noncalcareous dark-grey argillite of the Kuznetsovskian Horizon. In the sample at depth $1016.4 \mathrm{~m}$ remains of bivalve shells as well as foraminifera were found. In Early Turonian assemblage together with Gaudryinopsis angustus Podobina the representatives of Haplophragmoides, Trochammina and Gaudryinopsis genera are predominant, the number of index-species of shells in some samples attaining 50 and more specimens. In addition to Trochammina wetteri Stelck et Wall, this species significantly prevails in terms of quantity over other species. The species composition of the assemblage together with index-species Gaudryinopsis angustus is the following: Psammosphaera laevigata White, Saccammina complanata (Franke), Lituotuba confusa (Zaspelova), Reophax inordinatus Young, Labrospira collyra (Nauss), Haplophragmoides rota Nauss sibiricus Zaspelova, H. crickmayi Stelck et Wall, Asarotammina antisa Podobina, Ammomarginulina haplophragmoidaeformis (Balakhmatova), Haplophragmium incomprehensis (Ehremeeva), Trochammina subbotinae Zaspelova, Trochammina wetteri Stelck et Wall, Gaudryinopsis angustus Podobina, Pseudoclavulina hastata (Cushman), Uvigerinammina manitobensis (Wickenden). Shells with the exception of completely white azarotammin and lituotrub are of light-grey colour with a predominant fine-grained structure of the wall. Among the enumerated species for the part of the section concerned (lower Turonian), Ammomarginulina haplophragmoidaeformis (Balakhmatova), Uvigerinammina manitobensis (Wickenden), Gaudryinopsis angustus Podobina are the most characteristic ones. In the assemblage Trochammina and Gaudrynopsis are predominant which suggests relatively deep-water and favourable conditions of existence. In one sample at depth $1019.6 \mathrm{~m}$ foraminifera shells are coarse-grained, index-species is individual. By 
and large, the assemblage, however, is Early Turonian although the conditions of shells' dwelling at the indicated depth were less favourable as compared with Early Turonian foraminifera associations lying above. (Figure 3 and Figure 4)

In sample at depth $1019.6 \mathrm{~m}$ remains of bivalve shells as well as foraminifera were found.

Unfortunately, between the selection depth of the lower sample from the Kuznetsovskian Horizon and the samples from the upper parts of the Uvatskian Horizon a significant interval in core selection is observed and therefore, we did not manage to trace the boundary between the indicated horizons and hence that of the lower Turonian and upper Cenomanian stages (Figure 5).

The boreal transgression which began in Late Cenomanian significantly expanded in Early Turonian and occupied the territory of not only the Parusovaya area being studied but spread all over Western Siberia: in the south it came to the Kazakhstan hills, in the west-up to the Urals, and in the east it is observed up to the meridian of Napas settlement (on the Tym river) [15]. The hydrological regime (depth, temperature, chemical composition of water and other factors) was favourable for a widespread foraminiferal development of Early Turonian assemblage with Gaudryinopsis angustus.

\section{Results of the Research}

Twenty core samples selected from the section of borehole 1016 of the Parusovaya area have been studied. From each sample of the section concerned mainly represented by grey aleurolites and millstone grits (the Uvatskian Horizon) and dark-grey argillites (the Kuznetsovskian Horizon) agglutinated quartz-siliceous foraminiferal shells have been discovered. Late Cenomanian foraminifera were determined in the Uvatskian Horizon. Figure 2 illustrates the Late Cenomanian foraminiferal assemblage at depth $1041.95 \mathrm{~m}$. As opposed to the other samples selected from the Uvatskian Horizon, the foraminiferal assemblage with Gaudryinopsis nanushukensis elongatus has been established here. In the other sections of the northern palaeobiogeographical district (Van-Eganskaya area) [14], the layers with this assemblage are the bottom of Late Cenomanian zone with Trochammina wetteri tumida, Verneuilinoides kansasensis. In the section of the Uvatskian Horizon, borehole 1016 of Parusovaya area (interval 1032.8 - 1048.05 $\mathrm{m})$ poorly preserved agglutinated foraminifera has been found in other specimens. Therefore, Figure 5 ("index-species" column) shows a general Late Cenomanian foraminiferal assemblage without indicating the index-species of the upper zone.

In contrast to the Late Cenomanian, shells of Early Turonian foraminifera assemblage are well-preserved, and have been found their characteristic species, including Gaudryinopsis angustus Podobina index-species. According to the number of specimens in the assemblage, the representatives of Ataxophragmiida order are predominant which is indicative of a favourable hydrological regime of a marine basin (depth, temperature, salinity, gas composition) which is asso- 
ciated with deepening and expanding Early Turonian boreal transgression.

This transgression, as contrasted to the Late Cenomanian one, occupied almost in the entire territory of Western Siberia that contributed to the foraminiferal assemblage development together with Gaudryinopsis angustus encompassing all species characteristic of the Kuznetsovskian Horizon.

Figure 3 and Figure 4 illustrate the main species of the assemblage concerned from borehole 1016 (Figure 3, depth 1016.65 m, Figure 4, depth $1017.4 \mathrm{~m}$ ). The encompassing deposits of the interval which refers to the Kuznetsovskian Horizon (interval 1006.4 - $1020.55 \mathrm{~m}$ ) as evidenced by foraminifera, correspond to lower Turonian (the lower part of the Kuznetsovskian Horizon) and are a good biostratigraphic reper.

The correlation of the Late Cenomanian-Turonian foraminiferal (micropalaeontological) zones of West Siberian and the Canadian provinces within the boundaries of the Arctic palaeobiogeographical realm is provided (see Table 1).

Micropalaeontological zones of the Cenomanian-Turonian of the West Siberian province correspond to those of the Canadian province (Western Canada, Northern Alaska), which suggests a similarity of the conditions of their dwelling. Taxa (genera, species) of agglutinated quartz-siliceous forms are predominant. In the lower Turonian of the Canadian province a layer of pelagic forms (Pelagic, genera Hedbergella) has been observed. Just the same layers have been found at this stratigraphic level within the range of some sections of boreholes (borehole 1002, the Van-Eganskaya area, etc.) of the northern district of the West Siberian province.

\section{References}

[1] Podobina, V.M. (1995) Paleozoogeographic Regionalization of Northern Hemisphere Late Cretaceous Basin Based on Foraminifera. Proceedings of 4 th International Workshop on Agglutinated Foraminifera, Special Publication No. 3, 239-247.

[2] Podobina, V.M. (1989) Foraminifera and Zone Stratigraphy of Upper Cretaceous Age of Western Siberia. Publishing House of Tomsk State University, Tomsk, 175 p. (In Russian)

[3] Podobina, V.M. (2000) Foraminifera and Biostratigraphy of Upper Cretaceous Age of Western Siberia. Publishing House of NTL, Tomsk, 388 p. (In Russian)

[4] Podobina, V.M. (2009) Foraminifera, Biostratigraphy of Upper Cretaceous and Paleogene of Western Siberia. Publishing House of Tomsk State University, Tomsk, 430 p. (In Russian)

[5] McNeil, D. (1997) New Foraminifera from the Upper Cretaceous and Cenozoic of the Beaufort-Mackenzie Basin of Arctic Canada. No. 35, 95.

[6] Wall, J. (1983) Jurassic and Cretaceous Foraminiferal Biostratigraphy in the Eastern Sverdrup Basis, Canadian Arctic Archipelago. Bulletin of Canadian Petroleum Geology, 31, 246-281.

[7] Podobina, V.M. (2013) Foraminifera and Late Cenomanian-Turonian Biostratigraphy of the Northern Palaeobiogeographic District of Western Siberia. Geologos, 19, 201-227.

[8] Podobina, V.M. (2013) Palaezoogeographical Division into Districts of Western Si- 
beria during Late Cenoman (Based on Foraminifera). Vestnik of Tomsk State University, No. 371, 189-196. (In Russian)

[9] Zaspelova, V.S. (1948) Foraminifera of Upper Jura and Cretaceous Deposits of West-Siberian Lowland. Microfauna of the USSR. Collection of Papers 1, 189-210. (In Russian)

[10] Ehremeeva, A.I. and Belousova, N.A. (1961) Stratigraphy and Fauna of Foraminifera of Cretaceous and Paleogene Deposits of Eastern Urals Slope and Northern Kazakhstan. Materials on Geology and Economic Minerals of the Urals M., Issue 9, 3-189. (In Russian)

[11] Subbotina, N.N., et al. (1964) Foraminifera of Cretaceous and Palaegenic Deposits of West-Siberian Lowland. VNIGRI Papers. Publishing House "Nedra", No. 234, 321 p. (In Russian)

[12] Zakharov, V.I., Beizel, A.L. and Pokhialainen, V.P. (1989) Discovery of Marine Cenoman in the North of Siberia. Geology and Geophysics, 6, 10-13. (In Russian)

[13] Podobina, V.M. and Tanacheva, M.I. (1967) Stratigraphy of Gas-Bearing Upper Cretaceous Deposits of North-Eastern Districts of Western-Siberian Lowland. New Data on Geology and Economic Minerals of Western Siberia. Publishing House of Tomsk State University, No. 2, 89-99. (In Russian)

[14] Podobina, V.M. (2012) New Data on Foraminifera and Biostratigraphy of Upper Cenomanian of the Northern District of Western Siberia. Vestnik of Tomsk State University, Issue 361, 182-187. (In Russian)

[15] Podobina, V.M. (2012) New Data on Turonian Biostratigraphy and Foraminifera of Western Siberia. Vestnik of Tomsk State University, Issue 364, 181-184. (In Russian)

Submit or recommend next manuscript to SCIRP and we will provide best service for you:

Accepting pre-submission inquiries through Email, Facebook, LinkedIn, Twitter, etc. A wide selection of journals (inclusive of 9 subjects, more than 200 journals)

Providing 24-hour high-quality service

User-friendly online submission system

Fair and swift peer-review system

Efficient typesetting and proofreading procedure

Display of the result of downloads and visits, as well as the number of cited articles

Maximum dissemination of your research work

Submit your manuscript at: http://papersubmission.scirp.org/

Or contact ojg@scirp.org 